\title{
Virulence of Verticillium lecanii (Zimm.) Viegas Subcultures Grown on an Artificial Medium or its Natural Host Icerya Seychellarum (Hemiptera: Monophlebidae)
}

\author{
Saad'. A. S. A, E. H. Tayeb', R. M. Rasmy², M. F. El-Deeb ${ }^{2}$ and M. A. A. \\ Rezk $^{2}$
}

1- Plant Protection Dept., Faculty of Agric. (Saba Basha), Alex. Univ., Egypt

2- Agric. Res. Center, Alexandria, Egypt

\begin{abstract}
The virulence of the mother and subcultures of Verticillium lecanii (Zimm.) Viegas maintained on an artificial medium (MYB) was determined. Each passage obtained from the artificial medium was divided into two isolates, the first was left on the artificial medium to obtain the following passage, while the other was subsequently potentiated on a natural insecthost, the mealy bug Icerya seychellarum (Hemiptera: Monophlebidae). The $L T_{50}$ value on the mealy bug $I$. seychellarum exposed to a fungus concentration of $1.7 \times 10^{8}$ spores $/ \mathrm{ml}$ was calculated. The $\mathrm{LT}_{50}$ value of the different subcultures (passages) on the natural host was as low as 4.6 days for the zero (mother) passage followed by 5.8, 7.4, 11.3,13.9 and 17.7 days for the five derived passages (subcultures on MYB ), respectively, while these values were low for those subcultures potentiated on I. seychellarum. The higher mortality percentage (100\%) was obtained after 13 days using the zero passage (mother culture) followed by 94.4, 79.8, 51.7, 44.9 and $36.0 \%$ mortality for $1^{\text {st }}, 2^{\text {nd }}, 3^{\text {rd }}$, 4 th and $5^{\text {th }}$ subcultures (passages) maintained through the used artificial medium [MYB]), respectively. These results proved that the ascending number of passages of $V$. lecanii through the used artificial medium (MYB) loses its virulence against $I$. seychellarum. On the other hand, these results proved that potentiation of $V$. lecanii passages on a suitable insect-host (I. seychellarum) increase its virulence again and shorten the period of $\mathrm{LT}_{50}$. Comparing the five passages potentiated on the natural insect-host ( $I$. seychellarum) and those revealed that have been continuously maintained on the artificial medium, it was found that the virulence of the potentiated subcultures obtained from the natural insect-host was increased by 1.9 fold for the $5^{\text {th }}$ passage relative to the virulence of the same continuously obtained subculture from the artificial medium.
\end{abstract}

Key words: Virulence, Verticillium lecanii, Icerya seychellarum, artificial media

\section{INTRODUCTION}

Virulence of the entomopathogenic fungi is affected by repeated successive subculturing in artificial media or passages through its insect hosts. Through successive subculturing on artificial media Constancy of fungal virulence is a desirable for biocontrol agents' production (Brownbridge et al., 2001; Vandenberg and Cantone, 2004). Enhancement of entomopathogenic fungi virulence following repeated subculturing in artificial media or passage through insect hosts has been reported (Kawakami, 1960; Schaerffenberg, 1964; Fargues and Robert, 1983). Some studies have reported that successive cultures in artificial media cause attenuation in fungal virulence. However, other studies proved no decline in virulence of fungi, subcultured in artificial media (Ansari and Butt, 2011; Brownbridge et al., 2001; Vandenberg and Cantone, 2004). Single passage of these fungi through a suitable host can restore or increase the virulence. While some studies reported that virulence needs two or more successive passages to be increeased (Butt et al., 2006). The effect of repeated subculturing in vitro and vivo passaging on viability, morphological characteristics and virulence, varies within entomopathogenic fungi strains 
(Cooper and Sweeney 1986; Guedes-Frazzon et al., 2000). Several studies suggested that the effect of repeated in vitro and has an impact on virulence in vivo passaging on the virulence of entomopathogenic fungi (Hajek et al., 1990) For some unknown reason, virulence may be temporarily restored in some subcultures but the overall trend is a decline. Asghar (2013) investigated the effects of repeated subculturing of Beauveria bassiana and Metarhizium anisopliae in vitro and passages through insects on their virulence against Uvarovistia zebra. The virulence of both fungi was reduced after four subcultures in Potato Dextrose Agar (PDA) media, but this reduction was not quite significant for $B$. bassiana. Attenuated fungi obtained from the fourth subculturing were passaged through $3^{\text {rd }}$ instar nymphs of Uvarovistia zebra. The insect passage was repeated two times and the fungi virulence was evaluated by calculating mortality percent. Following passage there was a small, but non-significant increase in the fungi virulence. This study aimed to determine the virulence of subcultures of the entomopathogenic fungus Verticillium lecanii derived either form an artificial diet or from rearing on a natural insect-host (Icerya seychellarum).

\section{MATERIALS AND METHODS}

The tested fungus and insects : The entomopathogenic fungus Verticillium lecanii (Zimmerman) viegas which was reclassified by Zare and Gams (2001) as Lecanicillium lecanii with a high virulent pathogenicity against scale insects and mealy bugs it was originally isolated from Alaska (USA and EMCC Number: $919^{\mathrm{TM}}$ ). The culture was obtained from Egypt microbial culture collection (Ain Shams Univ., Egypt). The adult individuals of the mealy bug Icerya seychellarum were reared on citrus leaves which have been replaced in Petri dish surrounded with a wet tissue paper to keep it fresh as insect host medium.

Fungal maintenance and conidial preparations: Medium cultures were maintained on sabouraud dextrose agar (SDA) media (10g mycopeptone, $40 \mathrm{~g}$ dextrose, $15 \mathrm{~g}$ agar and $1000 \mathrm{ml}$ distilled water). For the fungal growth, malt agar with $0.1 \%$ yeast extract were added to SDA medium and kept for 10 days at $25^{\circ} \mathrm{C}$. Spores were harvested with an aqueous solution of $0.05 \%$ Triton $100^{\circledR}$. The spore suspension was filtered through several layers of cheese cloth to remove mycelial mats. The concentration of spores in the final suspension was determined using a haemocytometer and adjusted for bioassay was by dilution with $0.05 \%$ Triton -100 to a final stock concentration of $1.7 \times 10^{8} \mathrm{spores} / \mathrm{ml}$. This procedure was done according to (Mehta et al, 2012).

Conidial subculturing on artificial media : For subculturing and repeated in vitro spore transfers, the spores were harvested from the surface of 10 days old culture by scraping with a loop and subcultured to fresh molasses yeast broth (MYB) (30g molasses, $5 \mathrm{~g}$ yeast and $1000 \mathrm{ml}$ distilled water). Cultured fungi were incubated at $28^{\circ} \mathrm{C}$. This multi-spore in vitro transfer was repeated up to 4 times. Before subculturing, a suspension of harvested spores was prepared to be used for bioassay and inoculate other insects. This procedure was done according to (Asghar,2013). 
Conidial passaging through insect: For the in vivo passage of the fungus maintained in the insect-host, spores of the $1^{\text {st }}, 2^{\text {nd }}, 3^{\text {rd }}, 4^{\text {th }}$ and $5^{\text {th }}$ in vitro subcultures were recovered from Petri dishes and suspended in sterile distilled water. Spore concentration of the suspension was adjusted to $1.7 \times 10^{8}$ spores $/ \mathrm{ml}$. Adult individuals of the mealy bug Icerya seychellarum were dipped in the spore's suspension $\left(1.7 \times 10^{8}\right.$ spores $\left./ \mathrm{ml}\right)$ containing $0.02 \%$ Tween $80^{\circledR}$ solution and placed individually in a small plastic container. Inoculated insects were maintained on a lettuce until response (mortality) occurred. Dead insects were cleaned with cotton wool soaked with $70 \%$ ethanol and incubated at $28^{\circ} \mathrm{C}$ with $80-90 \%$ R.H to stimulate sporulation of the fungi. The spores from cadavers were harvested by scraping with a pointed needle and suspended in sterile distilled water to inoculate other insects. This insect passage was repeated and virulence of the fungi was evaluated by mortality through a bioassay. This procedure was done according to (Asghar,2013).

Rearing the tested insects: The immature individuals of the used mealy bug, Icerya seychellarum were reared on young citrus (orange) trees (1 year old). The trees were individually infested with 60 immature mealy bugs. Four weeks after the initial infestation, the settled adults of $I$. seychellarum were observed and used for bioassay measuring the fungi virulence. (rezk,2009)

Bioassay procedure: The virulence of the evaluated fungi was assayed (i) with the original isolates before subculturing on artificial media (ii) after subculturing on artificial media, and (iii) after in vivo passage in the insect.

Adult individuals of the mealy bug, I. seychellarum were assayed on citrus trees (30 insects/ young tree) grown in a green house and the trees were sprayed with spore suspension $\left(1.7 \times 10^{8}\right.$ spores $/ \mathrm{ml}$ ). Six treatments (sub cultures) were used. mother culture, $1^{\text {st }}, 2^{\text {nd }}, 3^{\text {rd }}, 4^{\text {th }}$ and $5^{\text {th }}$ passage culture through artificial medium and an insect host Icerya seychellarum (Hemiptera: Monophlebidae) beside the untreated check three replicates were considered one treatment. The fungi virulence was measured through daily calculation of mortality percent within mortality 14 days post fungal application. This procedure was done according to (Asghar, 2013).

Statistical analysis: The percentages of corrected cumulative mortalities (Abbott, 1925) of each treatment and the mean were calculated with Microsoft excel program (means $\pm \mathrm{SD}$ ). And the data were analyzed with the Lpd-line program to calculate LT50 values (Finney, 1971).

\section{Results and Discussion}

The entomopathogenic fungi are known to lose their desirable features after repeated sub-culturing declining their virulence through successive passages (subcultures). Verticillium lecanii, which lose virulence, may sometimes be restored to their former potency by passing them through their insect host. The results of the effect on virulence of V.lecanii (Zimm.) Viegas passage through an artificial medium and an insect host $I$. seychellarum are recorded in Tables (1 and 2) from which, it could be deduced that. The mortality and LT50 values of the adult individuals of the mealy bug I. seychellarum exposed to mother and its obtained was according to differed the tested 
subcultures, time of exposure and the used medium at a single concentration of $1.7 \times 10^{8} \mathrm{spores} / \mathrm{ml}$. Daily recorded mortality percent proved that the lethal effects of the tested cultures were systematically arranged with increasing the time of exposure in all cases (subcultures) reaching to $94.4,79.8,51.7,44.9$ and $36 \%$ mortality percent in treatment with $1^{\text {st }}, 2^{\text {nd }}, 3^{\text {rd }}, 4^{\text {th }}$ and $5^{\text {th }}$ sub cultures, respectively when passaged through the MYB artificial medium compared with complete death (100\% mortality ) of the insect population treated with the mother culture after 13 days. These results proved that the virulence of $V$. lecanii against $I$. seychellarum was decreased with increasing its passage's number through the MYB artificial medium. This was clear when the $\mathrm{LT}_{50}$ values of the different passages through the artificial medium (MYB) were compared. The lowest value of $L T_{50}$ for the zero passage is 4.6 days followed by 5.8, 7.4, 11.3, 13.9 and 17.7 days for the five passages cultures, respectively (Table 2).

Moreover, these results also confirmed that the passages of $V$. lecanii through a suitable insect-host, I. seychellarum have an increase of their virulence, showing the lowest value of $\mathrm{LT}_{50}$ (4.6 days) for the zero passage followed by 5.3, 6.6, 8.4, 9.0 and 9.47 days for the five derived passages (subcultures), respectively . Comparing the five passages through the natural insect-host, I. seychellarum with the used artificial medium, it was found that virulence of subcultures obtained form the natural insect host was increased by 1.9 fold relative to that of subcultures obtained from the artificial medium Bo base on their $\mathrm{LT}_{50}$ value.

The obtained results are in agreement with Nagaich (1973) who found loss of virulence of V.lecanii (Zimm.) after two or three subculturing. Meanwhile, some strains need to be successively subcultured 10 to 12 times before a significant decline in virulence is occurred.

On the other hand, Asghar (2013) reported on the effects of repeated subculturing of Beauveria bassiana and Metarhizium anisopliae in vitro and their passages through insects and their virulence against Uvarovistia zebra. The virulence of both fungi was reduced after four subcultures in Potato Dextrose Agar media (PDA), but this reduction was not quite significant for $B$. bassiana. Attenuated fungi obtained from the fourth subculturing were passaged through $3^{\text {rd }}$ effects instar nymphs of $U$. zebra. The insect passage was repeated 2 times and virulence of the fungi was evaluated by its lethal. Following passage there was a small, but non-significant increase in the virulence of the fungi. 
Table (1): Mortality effects on Icerya seychellarum at $1.7 \times 10^{8}$ spores $/ \mathrm{ml}$ of Verticillium lecanii derived from different passages, maintained on MYB medium and it's Insect-hos

\begin{tabular}{|c|c|c|c|c|c|c|c|c|c|c|c|c|c|c|c|c|}
\hline \multirow{2}{*}{$\begin{array}{l}\text { Culture strain } \\
\text { (passage) }\end{array}$} & \multirow{2}{*}{ Medium type } & \multirow[t]{2}{*}{$\begin{array}{l}\text { Pre- } \\
\text { spray }\end{array}$} & \multicolumn{14}{|c|}{ Mortality percents at different times (days) } \\
\hline & & & 1 & 2 & 3 & 4 & 5 & 6 & 7 & 8 & 9 & 10 & 11 & 12 & 13 & 14 \\
\hline Untreated check & & $\begin{array}{l}0.0 \\
0.0\end{array}$ & $\begin{array}{c}0.0 \\
\pm 0.0\end{array}$ & $\begin{array}{r}0.0 \\
\pm 0.0\end{array}$ & $\begin{array}{c}1.1 \\
\pm 1.9\end{array}$ & $\begin{array}{c}1.1 \\
\pm 1.9\end{array}$ & $\begin{array}{c}1.1 \\
\pm 1.9\end{array}$ & $\begin{array}{c}1.1 \\
\pm 1.9\end{array}$ & $\begin{array}{c}1.1 \\
\pm 1.9\end{array}$ & $\begin{array}{c}1.1 \\
\pm 1.9\end{array}$ & $\begin{array}{c}1.1 \\
\pm 1.9\end{array}$ & $\begin{array}{c}1.1 \\
\pm 1.9\end{array}$ & $\begin{array}{c}1.1 \\
\pm 1.9\end{array}$ & $\begin{array}{c}1.1 \\
\pm 1.9\end{array}$ & $\begin{array}{c}1.1 \\
\pm 1.9\end{array}$ & $\begin{array}{c}1.1 \\
\pm 1.9\end{array}$ \\
\hline Mother culture & MYB & $\begin{array}{l}0.0 \\
0.0\end{array}$ & $\begin{array}{c}2.2 \\
\pm 1.9\end{array}$ & $\begin{array}{c}6.7 \\
\pm 2.7\end{array}$ & $\begin{array}{l}29.1 \\
\pm 8.1\end{array}$ & $\begin{array}{l}53.9 \\
\pm 1.1\end{array}$ & $\begin{array}{l}57.3 \\
\pm 2.5\end{array}$ & $\begin{array}{l}60.7 \\
\pm 1.2\end{array}$ & $\begin{array}{l}64.1 \\
\pm 1.3\end{array}$ & $\begin{array}{l}65.2 \\
\pm 1.7\end{array}$ & $\begin{array}{l}75.3 \\
\pm 1.7\end{array}$ & $\begin{array}{l}88.7 \\
\pm 1.8\end{array}$ & $\begin{array}{l}93.3 \\
\pm 0.1\end{array}$ & $\begin{array}{l}95.5 \\
\pm 1.9\end{array}$ & $\begin{array}{c}100.0 \\
\pm 0.0\end{array}$ & $\begin{array}{c}100.0 \\
\pm 0.0\end{array}$ \\
\hline \multirow{2}{*}{$1^{\text {st }}$ passage } & MYB & 0.0 & $\begin{array}{c}1.1 \\
\pm 1.9 \\
\end{array}$ & $\begin{array}{c}4.4 \\
\pm 1.6 \\
\end{array}$ & $\begin{array}{l}16.9 \\
\pm 0.3 \\
\end{array}$ & $\begin{array}{l}35.9 \\
\pm 1.3 \\
\end{array}$ & $\begin{array}{l}44.9 \\
\pm 3.1 \\
\end{array}$ & $\begin{array}{l}46.0 \\
\pm 1.0 \\
\end{array}$ & $\begin{array}{l}57.3 \\
\pm 2.5 \\
\end{array}$ & $\begin{array}{l}61.8 \\
\pm 1.7 \\
\end{array}$ & $\begin{array}{l}66.3 \\
\pm 0.7 \\
\end{array}$ & $\begin{array}{l}76.4 \\
\pm 0.5 \\
\end{array}$ & $\begin{array}{l}87.6 \\
\pm 2.1 \\
\end{array}$ & $\begin{array}{l}89.9 \\
\pm 0.2 \\
\end{array}$ & $\begin{array}{l}94.4 \\
\pm 1.9 \\
\end{array}$ & $\begin{array}{r}94.4 \\
\pm 1.9 \\
\end{array}$ \\
\hline & I.seychellarum & 0.0 & $\begin{array}{c}1.1 \\
\pm 1.9\end{array}$ & $\begin{array}{c}4.4 \\
\pm 1.6\end{array}$ & $\begin{array}{l}25.8 \\
\pm 1.5\end{array}$ & $\begin{array}{l}50.5 \\
\pm 2.6\end{array}$ & $\begin{array}{l}51.7 \\
\pm 1.7\end{array}$ & $\begin{array}{l}55.1 \\
\pm 1.7\end{array}$ & $\begin{array}{l}56.2 \\
\pm 0.9\end{array}$ & $\begin{array}{l}57.3 \\
\pm 2.5\end{array}$ & $\begin{array}{l}64.1 \\
\pm 1.3\end{array}$ & $\begin{array}{l}71.8 \\
\pm 1.6\end{array}$ & $\begin{array}{l}82.0 \\
\pm 1.8\end{array}$ & $\begin{array}{l}89.0 \\
\pm 0.2\end{array}$ & $\begin{array}{l}95.5 \\
\pm 1.9\end{array}$ & $\begin{array}{l}98.9 \\
\pm 1.9\end{array}$ \\
\hline \multirow{2}{*}{$2^{\text {nd }}$ passage } & MYB & 0.0 & $\begin{array}{c}1.1 \\
\pm 1.9\end{array}$ & $\begin{array}{c}3.3 \\
\pm 4.4\end{array}$ & $\begin{array}{c}6.7 \\
\pm 0.1\end{array}$ & $\begin{array}{l}25.9 \\
\pm 2.2\end{array}$ & $\begin{array}{l}38.2 \\
\pm 1.7\end{array}$ & $\begin{array}{l}39.3 \\
\pm 1.2\end{array}$ & $\begin{array}{l}44.9 \\
\pm 3.1\end{array}$ & $\begin{array}{l}47.2 \\
\pm 0.9\end{array}$ & $\begin{array}{l}51.7 \\
\pm 1.7\end{array}$ & $\begin{array}{l}65.2 \\
\pm 1.7\end{array}$ & $\begin{array}{l}73.0 \\
\pm 0.5\end{array}$ & $\begin{array}{l}74.1 \\
\pm 2.2\end{array}$ & $\begin{array}{l}79.8 \\
\pm 0.4\end{array}$ & $\begin{array}{l}83.1 \\
\pm 0.3\end{array}$ \\
\hline & I.seychellarum & 0.0 & $\begin{array}{r}1.1 \\
\pm 1.9\end{array}$ & $\begin{array}{r}5.6 \\
\pm 1.6\end{array}$ & $\begin{array}{r}17.9 \\
\pm 1.8 \\
\end{array}$ & $\begin{array}{r}25.9 \\
\pm 2.2 \\
\end{array}$ & $\begin{array}{r}35.9 \\
\pm 1.3 \\
\end{array}$ & $\begin{array}{r}41.6 \\
\pm 1.7 \\
\end{array}$ & $\begin{array}{r}53.9 \\
\pm 1.1 \\
\end{array}$ & $\begin{array}{r}57.3 \\
\pm 2.5\end{array}$ & $\begin{array}{r}59.5 \\
\pm 0.8\end{array}$ & $\begin{array}{l}62.9 \\
\pm 0.7\end{array}$ & $\begin{array}{r}67.4 \\
\pm 2.3\end{array}$ & $\begin{array}{r}83.1 \\
\pm 0.3 \\
\end{array}$ & $\begin{array}{r}89.9 \\
\pm 0.2\end{array}$ & $\begin{array}{r}92.1 \\
\pm 2.1 \\
\end{array}$ \\
\hline \multirow{2}{*}{$3^{\text {rd }}$ passage } & MYB & 0.0 & $\begin{array}{r}1.1 \\
\pm 1.9 \\
\end{array}$ & $\begin{array}{r}2.2 \\
\pm 1.6 \\
\end{array}$ & $\begin{array}{r}2.2 \\
\pm 1.9 \\
\end{array}$ & $\begin{array}{l}13.5 \\
\pm 0.3 \\
\end{array}$ & $\begin{array}{l}23.6 \\
\pm 0.5\end{array}$ & $\begin{array}{l}31.5 \\
\pm 1.7\end{array}$ & $\begin{array}{l}34.8 \\
\pm 1.7 \\
\end{array}$ & $\begin{array}{l}37.1 \\
\pm 0.7 \\
\end{array}$ & $\begin{array}{l}40.5 \\
\pm 0.8 \\
\end{array}$ & $\begin{array}{l}47.2 \\
\pm 0.2\end{array}$ & $\begin{array}{l}49.4 \\
\pm 0.9\end{array}$ & $\begin{array}{l}51.7 \\
\pm 1.7\end{array}$ & $\begin{array}{l}51.7 \\
\pm 1.7\end{array}$ & $\begin{array}{l}55.0 \\
\pm 1.7\end{array}$ \\
\hline & I.seychellarum & 0.0 & $\begin{array}{c}1.1 \\
\pm 1.9\end{array}$ & $\begin{array}{c}1.1 \\
\pm 1.6\end{array}$ & $\begin{array}{r}4.5 \\
\pm 1.9\end{array}$ & $\begin{array}{c}6.7 \\
\pm 0.1\end{array}$ & $\begin{array}{l}22.4 \\
\pm 3.7\end{array}$ & $\begin{array}{l}31.5 \\
\pm 1.7\end{array}$ & $\begin{array}{l}43.8 \\
\pm 2.7\end{array}$ & $\begin{array}{l}49.4 \\
\pm 1.0\end{array}$ & $\begin{array}{l}51.7 \\
\pm 1.7\end{array}$ & $\begin{array}{l}57.3 \\
\pm 2.5\end{array}$ & $\begin{array}{l}62.9 \\
\pm 0.7\end{array}$ & $\begin{array}{r}70.8 \\
\pm 1.4\end{array}$ & $\begin{array}{l}73.0 \\
\pm 0.5\end{array}$ & $\begin{array}{l}83.1 \\
\pm 0.3\end{array}$ \\
\hline \multirow{2}{*}{$4^{\text {th }}$ passage } & MYB & 0.0 & $\begin{array}{r}1.1 \\
\pm 1.9 \\
\end{array}$ & $\begin{array}{r}1.1 \\
\pm 1.6 \\
\end{array}$ & $\begin{array}{r}1.1 \\
\pm 1.9 \\
\end{array}$ & $\begin{array}{c}6.7 \\
\pm 0.1\end{array}$ & $\begin{array}{l}10.1 \\
\pm 0.2 \\
\end{array}$ & $\begin{array}{l}20.2 \\
\pm 0.4 \\
\end{array}$ & $\begin{array}{l}28.1 \\
\pm 1.7 \\
\end{array}$ & $\begin{array}{r}32.6 \\
\pm 1.3 \\
\end{array}$ & $\begin{array}{l}33.7 \\
\pm 0.7 \\
\end{array}$ & $\begin{array}{r}35.9 \\
\pm 1.3 \\
\end{array}$ & $\begin{array}{l}38.2 \\
\pm 1.7\end{array}$ & $\begin{array}{r}43.8 \\
\pm 0.9 \\
\end{array}$ & $\begin{array}{r}44.9 \\
\pm 1.7\end{array}$ & $\begin{array}{r}46.0 \\
\pm 1.1 \\
\end{array}$ \\
\hline & I.seychellarum & 0.0 & $\begin{array}{c}1.1 \\
\pm 1.9\end{array}$ & $\begin{array}{c}1.1 \\
\pm 1.6\end{array}$ & $\begin{array}{c}5.6 \\
\pm 2.0\end{array}$ & $\begin{array}{l}10.1 \\
\pm 0.2\end{array}$ & $\begin{array}{l}21.3 \\
\pm 1.8\end{array}$ & $\begin{array}{l}24.7 \\
\pm 1.7\end{array}$ & $\begin{array}{l}30.3 \\
\pm 0.6\end{array}$ & $\begin{array}{l}42.7 \\
\pm 1.1\end{array}$ & $\begin{array}{l}53.9 \\
\pm 1.1\end{array}$ & $\begin{array}{l}59.6 \\
\pm 2.7\end{array}$ & $\begin{array}{l}60.7 \\
\pm 1.2\end{array}$ & $\begin{array}{l}65.2 \\
\pm 3.3\end{array}$ & $\begin{array}{l}67.4 \\
\pm 1.3\end{array}$ & $\begin{array}{l}76.4 \\
\pm 0.5\end{array}$ \\
\hline \multirow{2}{*}{$5^{\text {th }}$ passage } & MYB & & $\begin{array}{r}1.1 \\
\pm 1.9 \\
\end{array}$ & $\begin{array}{c}1.1 \\
\pm 1.6 \\
\end{array}$ & $\begin{array}{r}1.1 \\
\pm 1.9 \\
\end{array}$ & $\begin{array}{c}3.4 \\
\pm 0.1 \\
\end{array}$ & $\begin{array}{r}4.5 \\
\pm 2.1 \\
\end{array}$ & $\begin{array}{r}7.9 \\
\pm 1.9 \\
\end{array}$ & $\begin{array}{r}11.2 \\
\pm 1.8 \\
\end{array}$ & $\begin{array}{r}15.7 \\
\pm 1.7 \\
\end{array}$ & $\begin{array}{l}20.2 \\
\pm 0.4 \\
\end{array}$ & $\begin{array}{l}26.9 \\
\pm 0.5 \\
\end{array}$ & $\begin{array}{l}32.6 \\
\pm 1.3 \\
\end{array}$ & $\begin{array}{l}33.7 \\
\pm 0.7 \\
\end{array}$ & $\begin{array}{r}35.9 \\
\pm 1.3 \\
\end{array}$ & $\begin{array}{r}38.2 \\
\pm 1.7 \\
\end{array}$ \\
\hline & I.seychellarum & 0.0 & $\begin{array}{c}1.1 \\
\pm 1.9\end{array}$ & $\begin{array}{r}2.2 \\
\pm 1.6\end{array}$ & $\begin{array}{c}6.7 \\
\pm 0.1\end{array}$ & $\begin{array}{r}12.3 \\
\pm 1.7\end{array}$ & $\begin{array}{l}22.4 \\
\pm 3.7\end{array}$ & $\begin{array}{l}23.6 \\
\pm 2.9\end{array}$ & $\begin{array}{r}31.5 \\
\pm 1.7\end{array}$ & $\begin{array}{l}43.8 \\
\pm 2.7\end{array}$ & $\begin{array}{l}48.3 \\
\pm 1.7\end{array}$ & $\begin{array}{l}51.7 \\
\pm 1.7\end{array}$ & $\begin{array}{l}52.8 \\
\pm 0.9\end{array}$ & $\begin{array}{l}62.9 \\
\pm 0.7\end{array}$ & $\begin{array}{l}68.5 \\
\pm 1.7\end{array}$ & $\begin{array}{l}73.0 \\
\pm 0.5\end{array}$ \\
\hline
\end{tabular}

Values are shown as mean \pm SD 
Table (2): $\mathrm{LT}_{50}$ values on Icerya seychellarum exposed to Verticillium lecanii (Zimm.) derived from different passages maintained through artificial media and an insect host ( $I$. seychellarum)

\begin{tabular}{c|c|c|c|c}
\hline $\begin{array}{c}\text { Tested culture of } \\
\text { Verticillium lecanii } \\
\text { (passage) }\end{array}$ & Medium type & $\mathrm{LT}_{50}$ (days) & Fiducially limits & Slope $( \pm \mathrm{SE})$ \\
\cline { 1 - 3 } Mother culture & MYB & 4.7 & $4.0-5.2$ & $3.2 \pm 0.2$ \\
1st passage & MYB & 5.8 & $5.5-6.1$ & $3.4 \pm 0.2$ \\
& I.seychellarum & 5.3 & $4.6-6.0$ & $3.0 \pm 0.1$ \\
2nd passage & MYB & 7.4 & $7.0-7.9$ & $3.1 \pm 0.2$ \\
& I.seychellarum & 6.6 & $6.1-7.1$ & $3.0 \pm 0.1$ \\
3rd passage & MYB & 11.3 & $10.4-12.4$ & $2.4 \pm 0.2$ \\
& I.seychellarum & 8.4 & $7.7-9.2$ & $3.5 \pm 0.2$ \\
4th passage & MYB & 13.9 & $12.6-15.6$ & $2.6 \pm 0.2$ \\
& I.seychellarum & 9.0 & $8.5-9.5$ & $3.3 \pm 0.2$ \\
5th passage & MYB & 17.7 & $15.7-24.1$ & $2.7 \pm 0.3$ \\
& I.seychellarum & 9.5 & $8.9-10.1$ & $3.0 \pm 0.2$ \\
\hline
\end{tabular}


The same trend as that presented in the present study was reported by Adames et al. (2011) as they assayed the virulence of strain M379 of the fungus, Metarhizium anisopliae (Metchnikoff) Sorokin (Hypocreales: Clavicipitaceae) after different passages through a suitable host using different concentrations for controlling of both acaricide-susceptible and resistant strains of the tick, Rhipicephalus (formerly Boophilus) microplus Canestrini (Ixodida: Ixodidae) in vitro. Where the highest value of $\mathrm{LC}_{50}$ for the susceptible strain corresponded to zero passage was $7.68 \times 10^{7}$ conidia $/ \mathrm{ml}$ followed by the fourth passage with $L_{50}$ of $2.68 \times 10^{7}$ and hence the lethal concentration was reduced to 2.87 -fold. Comparing $L_{50}$ values of the fourth vs. the seventh passage $\left(2.59 \times 10^{5}\right.$ conidia/ml $)$, it was found that the lethal concentration was reduced by 103.47 -fold for the seventh passage when the fungus Metarhizium anisopliae was maintained on ticks (natural host).

\section{References}

Adames, M., M. Fernández, G. Peña and V. Hernández. 2011. Effects of passages through a suitable host of the fungus, Metarhiziumanisopliae, on the virulence of acaricide-susceptible and resistant strains of the tick, Rhipicephalus microplus. J. Insect Sci., 11(21): 1-13.

Ansari M. A. and T. M. Butt. 2011. Effects of successive subculturing on stability, virulence,conidial yield, germination and shelf-life of entomopathogenic fungi, J. Appl. Microbiol., (110): 1460-1469.

Asghar, M. 2013. Virulence of Beauveriabassiana and Metarhiziumanisopliae (Hypocreales: Clavicipitaceae) passaged through artificial media and an insect host Uvarovistia zebra (Orthoptera: Tettigoniodae), Int. J. Agric Crop Sci., 6 (16): 1147-1152.

Brownbridge, M., S. Costa and S.T. Jaronski. 2001. Effects of in vitro passage of Beauveriabassiana on virulence of Bemisia argentifolii. J. Invert. Pathol., (77): 280- 283.

Butt, T. M., C. Wang, F. A. Shah and R. Hall. 2006. Degeneration of entomogenous fungi. In: An Ecological and Societal Approach to Biological Control, Eilenberg J, Hokkanen HMT, editors. pp. 213-226. Springer.

Cooper, R. and A. W. Sweeney .1986. Laboratory studies on the recycling potential of the mosquito pathogenic fungus Culicinomyces, J. Invert. Pathol., (48): 152-158.

Fargues, J. F. and P. H.Robert. 1983. Effect of passaging through scarabaeid hosts on the virulence and host specificity of two strains of the entomopathogenic hyphomycete Metarhizium anisopliae. Can. J. Microbiol., 29: $575-583$.

Finney, D.N. 1971. Probit analysis $3^{\text {rd }}$ Ed, Cambridge Unv. Press London pp: 318.

Guedes-Frazzon, A. P., I. Vaz Junior, A. Masuda, A. Schrank and M. Henning . 2000. In vitro assessment of Metarhizium anisopliae isolates to control the cattle tick Boophilus microplus, Vet. Parasitol., (94):117125. $b$ 
Hajek, A. E., R. A. Humber and M. H. Griggs .1990. Decline in virulence of Entomophagamaimaiga (Zygomycetes: Entomophthorales) with repeated in vitro Subculture. J. Invert. Pathol., 56: 91-97.

Kawakami, K. 1960. On the change of characteristics of the silkworm muscardines through successive cultures. Bull. Seric. Exp. Stn. Japan., 16: 83-99.

Mehta, J., D. J. Kiran, K. Ambika, S. Priya, K.Neha and D.Sakshi .2012 Biomass Production of Entomopathogenic Fungi using various Products in Kota Region, India I. Res. J. Biological Sci. Vol. 1(4), 12-16

Nagaich, B. B. 1973. Verticillium species pathogenic on aphids. Indian J.Pathol. Microbiol., 26: 163-165.

Schaerffenberg, B. 1964. Biological and environmental conditions for the development of mycoses caused by Beauveria and Metarhizium. Insect Pathol., 6: 8-20.

Rezk, M.A.A. 2009. Biological control of certain scale insects and mealybugs infesting certain fruit trees. MS. C. Thesis, Alexandria Univ., 95 pp.

Vandenberg, J. D. and F. A. Cantone. 2004. Effect of serial transfer of three strains of Paecilomyces fumosoroseus on growth in vitro, virulence and host specificity. J .Invert. Pathol., 85: 40-45.

Zare, R. and W.Gams. 2001. A revision of Verticillium sect. Prostrata. III. Generic classification. Nova Hedwigia., (72): 329- 337. 


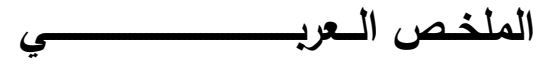

\title{
القدرة الممرضة للمزارع الثانوية من فطر قُرتيسيليم ليكاني المشتقة من البيئة الصناعية أو المقواة على العائل الحشري البق الدقيقي (أيسيريا سيشيلارم)
}

\author{
عبدالفتاح سيد عبدالكريم سعد' ، السيد حسن تايب' ، محمد رفت رسمي '،

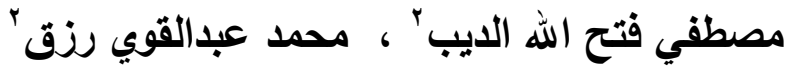

1 - قسم وقاية النبات - كلية الزراعة سابا باشا - جامعة الاسكندرية

r- مركز البحوث الزراعية - الاسكندرية

تم تقييم قدرة المزارع الثانوية من فطر فرتيسيليم ليكاني على إحداث المرض علي البق الدقيقي أيسيريا

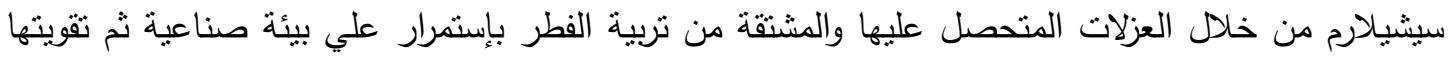

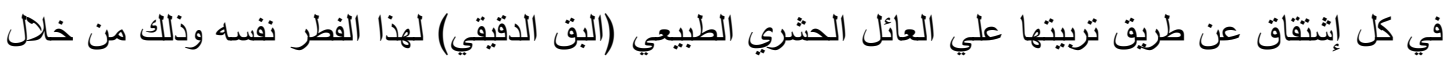

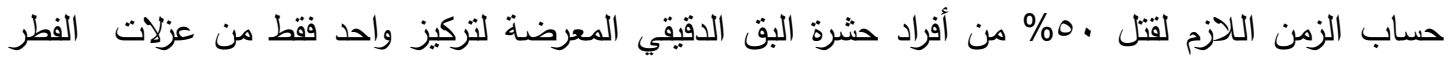

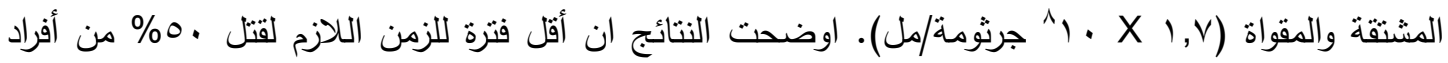

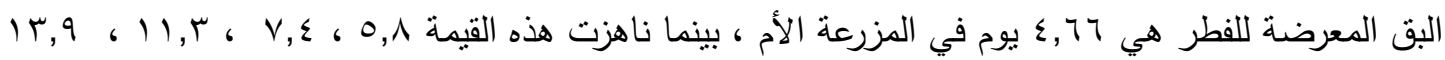
، ، يو V,V

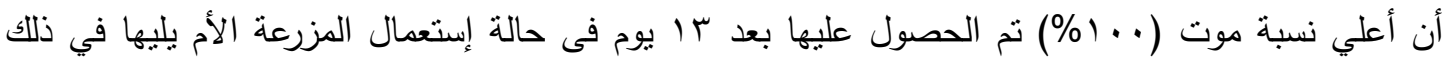

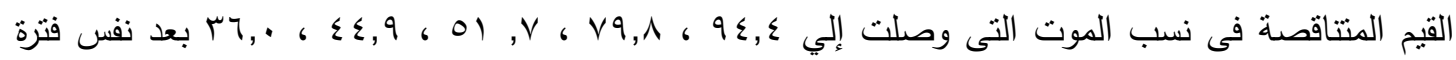

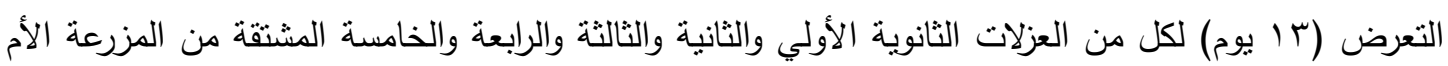
مما يوضح أن القدرة المرضية للفطر ضد عائله الحشري تتتاقص تدريجيا بزيادة إثتقاق المزارع أو العزلات

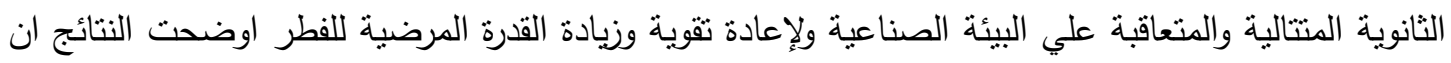
الفطر تزداد قدرتة وكفاءته فى إحداث المرض من خلال التزبية المنتالية علي العائل الحشري. حيث أمكن تحديد

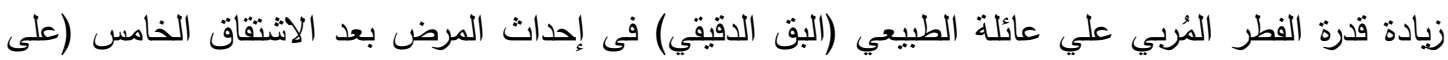
البيئة الصناعية) بلغت معدل أكبر قدر بـ 1,9 من قدرة الفطر المُربي باستمرار علي البيئة الصناعية وحدها

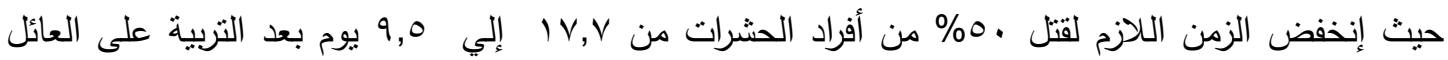

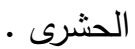

